\title{
HEALTH MANPOWER LICENSING AND EMERGING INSTITUTIONAL RESPONSIBILITY FOR THE QUALITY OF CARE
}

\author{
Rick J. Caruson*
}

\section{INTRODUCTION}

In rg62, Milton Friedman, discussing the growth of occupational licensure, urged its abolition even as to health care practitioners, who are generally considered the most critical subject for licensure. Professor Friedman did not equivocate:

I am myself persuaded that licensure has reduced both the quantity and quality of medical practice; that it has reduced the opportunities available to people who would like to be physicians, forcing them to pursue occupations they regard as less attractive; that it has forced the public to pay more for less satisfactory medical service, and that it has retarded technological development both in medicine itself and in the organization of medical practice. I conclude that licensure should be eliminated as a requirement for the practice of medicine. ${ }^{1}$

In Ig67 the National Advisory Commission on Health Manpower issued a twovolume work which included an extensive discussion of the licensure of health professionals. Its recommendations on this subject were more guarded, to say the least, than Friedman's:

Careful study, analysis, and consultation among the health professions will be necessary to develop guidelines for legislative resolution of the issue of delegation and other problems in licensure. ${ }^{2}$

Although the problems have been recognized and the challenge made, no effective, comprehensive reforms have yet occurred.

The Friedman argument is not the thesis of this article despite its prescience. His argument is founded in nineteenth century liberalism and laissez-faire dogma. The argument here looks forward and anticipates change in the system for delivering health care, particularly a further increase in government involvement—contra laissez faire-in the restructuring of the system.

The perpetuation of licensure is but one manifestation of the general reluctance of the health care establishment to act affirmatively for change. The purpose of this article is, therefore, to determine the necessity for reform of the licensure system for health professionals and to provide impetus for such reform if the necessity exists. The principal conclusion is that improved provision of health

\footnotetext{
* Research Attorney, Institute for Interdisciplinary Studies, Minneapolis, Minnesota.

1 M. Friedanan, Captralism and Freenom I58 (I962).

$3_{2}$ Report of the National Advisorx Commission on Health Manpower 332 (I967).
} 
care requires it. In view of this conclusion, a proposal for reform is advanced, with the caution that change in licensure laws will not alone solve the frequently documented crisis in health care nor galvanize the health care establishment to take the measures necessary to solve that crisis. It should, however, be a significant step in the right direction.

\section{I}

\section{CURRent Licensure Laws ${ }^{3}$}

Licensure of health manpower is a function of the state under its police power to legislate for the protection of health, safety, and welfare of its citizens. State medical societies sponsored the enactment of licensure laws in the late nineteenth and early twentieth centuries. ${ }^{4}$ Their success was surprising because the flourishing of laissez-faire philosophy had blunted other attempts to secure occupational licensure. The case was stronger, however, for health practitioner licensing: extragovernmental means of control, including efforts by medical societies, had proved ineffective in eliminating rampant incompetence and quackery. ${ }^{5}$

Early laws originated when there were few discernible health manpower categories. These statutes thus dealt only with physicians and authorized those with the specified qualifications to perform all health care functions. As new categories of health professionals developed and gained acceptance, their members were granted more circumscribed licenses enabling them to perform only those functions for which they were qualified by training and experience. ${ }^{0}$

Licensure laws covering health personnel have typically progressed from permissive (merely preventing the use of a given title by the unlicensed) to mandatory (making criminal any action within the scope of a licensed profession by one not licensed in that profession). Functional spheres are defined by statutes and/or by custom, and licensees zealously protect their functional perimeters against encroachment from the outside. As more functions have come within the practical competence

\footnotetext{
${ }^{8}$ A fair amount of literature exists on the subject of health manpower licensure laws. Taken together, the various articles provide a comprehensive analysis which this article will not replicate in full. See generally B. Anderson, "Iicensure of Paramedical Personnel," paper presented at the 65th Annual Mceting of the Federation of State Medical Boards, r969; E. Egelston \& T. Kinser, Explorstory InvestionTION OF Licensure of Health Personnel (I969); Forgotson \& Cook, Innovations and Experiments in Uses of Health Manpower-The Effect of Licensure Laws, 32 LAw \& ContzMp. Prop. 73I (1967); Forgotson \& R. Roemer, Government Licensture and Voluntary Standards for Health Personnel and Facilities, 6 MED. CARE 345 (1968); Forgotson, R. Roemer \& Newman, Licensture of Physicians, 1967 Wash. U.L.Q. 249; Leff, Medical Devices and Paramedical Personnel: A Preliminary Context for Emerging Problems, I967 WASH. U.L.Q. 332; Moore, The Purpose of Licensing, 4 J. LAW \& EcoN. 93 (196I); $R$. Roemer, Legal Systems Regulating Health Personnel, 46 Mirbank Memorial Fund Q. 431 (1968).

'See L. Friedman, Freedom of Contract and Occupational Licensing 1890-19ro: A Legal and Social Study, 53 Calif. L. Rev. 487 (1965).

"See Forgotson, Roemer \& Newman, supra note 3. The authors document the catalytic cffect the Flexner report had upon medical practice quackery and medical school "diploma mills." See A. Frexner, Medicar Education in the United States and Canada (igro). Cf. Kessel, The A.M.A. and the Supply of Physicians, 35 LAw \& Contemp. Prob. 267 (1970).

- See Forgotson \& Cook, supra note 3 , at 735 .
} 
of personnel less extensively trained than the physician, and as health care demands have grown, these laws have impeded the allocation of different functions to existing allied health personnel and discouraged the development of new types of paramedical personnel. ${ }^{7}$

To place licensure laws in nationwide perspective, the following listing indicates the extent of licensure in the United States for various types of health care practitioners: 8

Licensed in all states: Dental hygienists, dentists, professional engineers (including those in the health field), optometrists, pharmacists, doctors of medicine, doctors of osteopathy, podiatrists, veterinarians, professional nurses, practical nurses.

Licensed in all but two states: Chiropractors, physical therapists.

Licensed in seventeen to thirty-six states: Midwives, opticians, psychologists, sanitarians.

Licensed in fewer than seventeen states: Clinical laboratory directors, clinical laboratory personnel, naturopaths, social workers.

Licensed in two states: Nursing home administrators.

Licensed in one state: Health department administrators, hospital administrators, $\mathrm{x}$-ray technicians.

At present twenty-five health professions and occupations enjoy the benefits of licensure in one or more states, and a single state may require licenses for anywhere from twelve to twenty-one categories of personnel. For example, California licenses twenty-one professions, followed by Florida, Hawaii, and New Jersey, each with twenty. ${ }^{9}$ Occupational therapists and dental assistants are not licensed in any state. Neither are such new categories as the physician's assistant or the health aides recently promoted by the Office of Economic Opportunity. ${ }^{10}$ However, some new types of personnel have been formally recognized by states in this manner in recent years, as evidenced by a statute passed in I 969 to license the "child health associate" in Colorado. ${ }^{11}$

${ }^{7}$ There is a discernible pattern to the emergence of health care professional groups. First, an association is formed; second, a trade journal is published; third, informal recognition is sought from other health care professional groups; fourth, demands are made to state legislatures for statutory recognition through licensure laws; and finally, having secured legislation, the group engages in boundary skirmishes with contiguous health care groups on the map of tasks and functions. For a perceptive discussion of this pattern, see Akers, The Professional Association and the Legal Regulation of Practice, 2 Law \& Soc. REv. 463 (r968).

'See A. Somers, Hospital Regulation: The Dilemma of Public Policy 79 (ig69).

'Id. See also M. Pennell \& P. Stuart, State Licensing of Health Occupations y-2 (Public Fealth Service Pub. No. I758, I968).

${ }^{10}$ However, physicians' assistants have been the object of other types of legislation, such as certification (California) and general delegation authorizations (Florida).

${ }^{11}$ Colo. Rev. Stat. \$ gr-ro-r (Permanent Cumulative Supp. 1969). 
II

\section{The Relationship Between Licensure and Medical Malpractice}

Licensure statutes affect malpractice law to the extent that in some states violations are admissible as evidence of negligence. ${ }^{12}$ The malpractice doctrine most directly related to health professional licensure law is the "standard of care" doctrine. $^{13}$ The notion underlying this doctrine is that in order to impose liability on a practitioner for the negligent performance of an act, there must be a discernible standard against which his performance can be measured. The doctrine is, of course, a facet of general negligence theory, which requires a duty with recognizable standards to be identified and imposed before a finding of negligence can be made.

If a person is injured in the course of medical treatment and an unlicensed aide or assistant was involved, and if the assistant was performing an act which only a person possessing a certain license is allowed to perform, the law of some states holds that the bare fact that a licensure statute was violated may create a presumption of negligence. ${ }^{14}$ The performance of extra-statutory acts by a licensed auxiliary may also lead to a presumption of negligence. ${ }^{15}$ Such a presumption, although not conclusive, makes it more likely that a finding of negligence on the part of the health assistant will result-because the presumption gives the plaintiffpatient an advantage which must be overcome by the defendant. In such a case, the presumption arises because utilization of the health practitioner in the particular instance did not conform to the legislative allocation of functions and hence presumably departed from the established standard of care. The unlicensed person may have in fact been more capable of performing the act than a licensed person. This, however, would not prevent the presumption of negligence from arising. The result is that providers (physicians and hospitals) may be inhibited (I) from employing and utilizing persons, otherwise capable and trained, for the performance of functions for which they are not licensed, and (2) from optimally utilizing licensed personnel for the performance of health care functions within their practical competence but beyond the scope of their licenses.

A point of great controversy is the extent to which the physician's fear of exposure to malpractice claims leads to distortion of his judgment in ministering to

\footnotetext{
${ }^{12}$ See, e.g., Monohan v. Devinny, 13 I Misc. 248, 225 N.Y.S. 60x (Sup. Ct. I927); Brown v. Shyne, 242 N.Y. 176 , I5I N.E. 197 (I926).

${ }^{13}$ See generally D. Loutselt \& H. Williams, Trtal of Medical Malpractice Cases ch. 8 (Supp. 1969). For specific treatment of the standard of care doctrine, see McCoid, The Care Required of Medical Practitioners, I2 VAND. L. REv. 549, 558-75 (1959).

${ }^{16}$ Practicing without any license or without a particular type of license is usually considered too remote in the chain of causation to constitute material evidence of negligence-although it may still be a criminal act. See generally Annot. 44 A.L.R. 1418 (1926); Annot. 57 A.L.R. 978 (1928). See also Willett v. Rowekamp, I34 O. St. 285, I6 N.E.2d 457 (1938); Janssen v. Mulder, 232 Mich. 183, 205 N.W. 159 (I925); Joly v. Mellor, I63 Wash. 48, 299 P. 660 (I93I).

${ }^{16}$ See, e.g., Monohan v. Devinny, I3I Misc. 248, 225 N.Y.S. 601 (Sup. Ct. 1927); Barber v. Reinking, 68 Wash. 2d I39, 4II P.2d 86I (1966).
} 
patient needs. The controversy does not wax over whether distortion arises but rather over to what extent it occurs. The argument may never be completely resolved, as physicians are understandably reluctant to detail unnecessary, defensive, and wasteful practices, and patients usually lack the sophistication to perceive such behavior. The possible consequences of such distortion in terms of the cost of medical care are, however, alarming. ${ }^{16}$

The interaction of malpractice and licensure laws, then, apparently produces two results. First, to the extent that current licensure laws are used as evidentiary tools in malpractice litigation, they unquestionably impede innovation, restrict the potential manpower pool, and frustrate efficient utilization of health manpower. Simply stated, licensure laws tend to lock practitioners into the functional spheres prescribed by statute, which frequently are not commensurate with actual abilities. Potential manpower resources will likely remain untapped due to the inability of many, otherwise desirous of employment, to satisfy statutory requirements for licensing. This is particularly and dismayingly true for the some 30,000 medics discharged annually from the armed services. ${ }^{17}$ Second, and closely related to the first, to the extent that licensure laws increase the risk or fear of malpractice litigation, they contribute to the escalation of health care costs.

The problems discussed in this section have not lacked attention. Solutions and remedies have been proffered by both legal commentators and health care researchers. Most of these proposals have, however, been premised on a conception of a static health care industry. This is not surprising since change in the system has been glacial at best. Nonetheless, change is occurring and will inevitably accelerate with sustained pressure on the system. The fact that proposals for change in the law affecting health manpower licensure reflect notions of a static industry tends to reduce their utility and may render ostensible reform efforts either counterproductive or obsolete at inception. In short, we must know something of the substance of the health care industry and the shape it is likely to take in the future before espousing fundamental legal changes. This is necessary if a change

\footnotetext{
${ }^{10}$ No definitive studies have been made of the actual cost increases which may be attributable to the threat of malpractice. Undoubtedly such a study wold be extremely complex. Dr. Michael Halberstam, in a recent article, his asserted that this threat affects physician behavior. While he cites no data to support his assertion, his article presents a perceptive account of such phenomena. See Halberstam, The Doctor's Dilemma-Will I Be Sued?' N.Y. Times, Feb. 14, 197x, Magazine at 8.

${ }^{17}$ Discharged medical corpsmen provide a vast potential supply of paraprofessionals. Many of them have had extensive health care services experience, occasionally in direct provision of care. Among the new training programs established to tap this source are the University of Washington's Medex progam and Duke University's Physicians Assistant program. For discussions of various paraprofessional manpower sources, see R. FeIn, The Doctor Shortage (1967); Light, Development and Growth of New Allied Health Fields, 2 ro J.A.M.A. II4 (I969).

Another point of critical importance is the impact that removing entry barriers would have on jobs available to the poor-including many blacks who have faced job discrimination which is at least as ubiquitous in health care as elsewhere. Black patients consume health care services proportionate to their percentage of the population and probably will consume a disproportionate amount once the health care system reaches them where they live. Despite these projections the chances of a black patient being seen by a black professional are currently very slight.
} 
in licensure is to have a positive impact on (a) the supply of personnel, (b) the utilization of such personnel, and $(c)$ the way in which the quality of care is regulated. Prior to discussing change, then, we must inquire into what is known about the industry and about supply, utilization, quality of care, and so on.

\section{III}

\section{The Organization of the Health Care Delivery System}

It is axiomatic that introducing change in one part of a system is unwarranted and premature if the ramifications of that change on other parts of the system have not been anticipated and analyzed. This type of systems analysis is particularly essential with respect to the health care system. Too often changes have been made without careful consideration of their impact-the tarnished examples of Medicare and Medicaid as financing mechanisms will serve to prove the point. ${ }^{18}$

The health care system has been called a "cottage industry."10 Health care is still provided principally by individual practitioners and diverse free-standing institutions. Few physicians have entered into formal arrangements with hospitals, with most engaging in solo practice and relating legally to such institutions as independent contractors. Occasionally, of course, practitioners and institutions will cluster together, but there has been no powerful centripetal force to facilitate integration of resources. One result is that the "cottage industry" has remained both labor intensive and grossly fragmented in contrast to the mechanization and integration in other industries. ${ }^{20}$

To oversimplify: Before the industrial revolution, commodities and many services were generally in sufficient supply only if the suppliers were physically present to deliver those goods and services. Change was introduced through market exchange mechanisms which both stimulated and followed intensive industrialization, in most instances resulting in a complex network to manage the supply flowing from producers to consumers. The products or services did not necessarily suffer from the increased complexity and may not even have cost more. This "train" of industrialization has swept past the health system-it simply has not

\footnotetext{
${ }^{18}$ While medical expenditures rose from $\$ 26$ billion in 1960 to $\$ 67.2$ billion in $1970,50 \%$ of the increase represented higher costs for the same services. Much of the increased cost occurred after 1965, the year Medicare and Medicaid were enacted. Although cost increases were foreseeable in 1965 , the dramatic escalations which actually occurred were not; it simply was not expected that physicians and hospitals would exploit these programs to the extent they have. The programs were designed to pay for services, and they have-but in far more units of care than predicted. This cost escalation and a persuasive explanation for it are discussed in Marmor, Why Medicare Helped Raise Doctors' Fees, TrunsAction, Sept. I968, at $\mathrm{r}_{4}$.

${ }^{10}$ See, e.g., Devey, Towards Automated Health Services, 57 ProceEdings of THe INST. Electrical \& Electronic Engineers 1830 (1967); Our Ailing Medical System, Fortune, Jan. 1970, at 79.

${ }^{20}$ Fragmentation, of course, is a conclusionary statement and not necessarily susceptible of empirical demonstration. As used here it has two meanings: first, that the health care is provided by many separate individuals, groups, and institutions, with few large organizations and little integration of practitioners and institutions; and second, that health manpower is classified by rigid licensure laws, resulting in the lack of a rational pattern of manpower availability and utilization.
} 
been reorganized to achieve integration of the resources for providing health care. It is still controlled by guilds and is particularly feudal in its deployment of laborspecifically, manpower employment, training, and utilization. ${ }^{21}$ Entry of new personnel and the utilization of existing personnel are restricted by rigid licensure laws and custom, the features of both deriving from professional sponsorship and activity.

There are some distinct problems associated with the organization of the delivery system for health care which derive in part from its anachronistic character and which interpenetrate manpower considerations. Discussion of these problems is essential to an understanding of the manifold implications of current licensure laws. The problems are discussed under the following headings: the industry's capacity; its structure; financing mechanisms; and the distribution of resources.

\section{A. Capacity of the Industry}

The health industry is marked by a shortage of licensed practitioners and an over-all excess of facilities. ${ }^{22}$ Although manpower shortages may be exaggerated

\footnotetext{
${ }^{31}$ References to the health care system in terms of industrialization are largely metaphorical. It is recognized that technological development has taken place in this sector; hospitals have employed many new devices, and the science has become very sophisticated in many ways. Consequently, the references to industrialization, guilds, and so forth are directed to the structure and organization of the system, and specifically to patterns of manpower utilization.

${ }^{23}$ Manpower shortages have been variously estimated. Some of the more dependable data reveals that there has been a steady decline in physicians per I00,000 of population. There will also be a projected shortage of ro0,000 nurses by 1975. See National Center for Health Statistics, Health Resources Statistics (Dep't of Health, Education, and Welfare, I969). The question of the adequacy of existing facilities depends generally on the nature of the organization of the health care system. If health care is financed by fees paid for services, hospital utilization tends to be as much a function of that financing mechanism as of the exercise of sound medical judgment. Given this arrangement, a determination that facilities are more than sufficient is highly questionable despite statistical sophistication. On the other hand, if health care is financed by prepayment where the providers bear the cost of institutionalization, unnecessary utilization is unlikely, and the sufficiency of facilities determined more by actual utilization practices. Under this latter measure too many institutional spaces are available assuming extrapolation from the data available on prepaid groups which do bear the costs of institutionalization once having entered into a contract to provide services in exchange for consumer prepayment. The entire question of shortages is occasionally paradoxical. Nathan Glazer, in a recent article, Paradoxes of Health Care, The PubLIC INTEREST, Winter 1971, at 62, quotes extensively from Robert Sigmond, a health planner on the question. Excerpts from Sigmond's comments follow:

"During the past year I have been conducting an informal, unscientific, unstructured, confidential survey. I have presented dozens and dozens of practicing physicians with the following hypothetical suppositions and questions:

"Suppose this country faced a national emergency like a long world war that required your region to contribute as many physicians, nurses and other health workers as possible. Suppose further that you were placed in charge of the health services in your region and were assured of the complete trust and cooperation of everyone. Would you be able to contribute any of the region's physicians, surgeons, nurses and other health workers for national emergency service, without impairing the quality of the health service provided in your region?

"Every single individual whom I questioned believed that if he could achieve complete cooperation and commitment, health manpower in the region could be substantially reduced without impairing quality of care and without adverse effect on the people's health. The unanimity of response was striking.
} 
by the severe maldistribution of personnel, they constitute one of the problems most frequently identified by health care organization exeprts and politicians alike.

Undeniably such shortages are exacerbated by licensure laws. To be employed in the health field, personnel must fit into licensure categories which vary from state to state but are uniformly restrictive in their application. Legal boundaries around manpower categories have led ineluctably to sub-optimal utilization by precluding the matching of skills with tasks to be performed. Entry barriers created by such laws restrict the supply of new manpower in the health field. State-to-state variations in licensure laws restrain interstate mobility, which possibly would alleviate the shortages caused by maldistribution. At present, millions are unemployed or underemployed in the United States; unemployment rates hover around five to six per cent. Reliable statistics are not available to demonstrate the degree of underemployment, but the phenomenon is presumed to be extensive. Relaxation of entry barriers would facilitate tapping this vast source of manpower. ${ }^{23}$

Despite encroachments on established tradition made by group practice ${ }^{24}$ and

'Even more striking were these physicians' responses with respect to the amount of reduction in health manpower that could be achieved without reducing the quality or effectiveness of service. When asked to estimate the proportion of the region's health manpower that could be released for national emergency service, the answers varied from about ro to 40 per cent, with an average of about 20 per cent.

"Equally as striking was the conviction of most of these doctors that the greatest proportion of health manpower could be spared among the most highly trained health personnel-physicians and nurses, for example, as contrasted with aides, orderlies, and kitchen workers.

"How would manpower reductions be achieved? ... There was a surprising consistency of basic themes.

"I. grouping physicians (and other practitioners) in organized settings and centralized locations so that they can make full use of lesser skilled but specially trained workers in their 'office practices' and thus provided more service per physician;

"2. locating more physicians' offices at hospitals and removing the distinction between 'office' and 'clinic' to reduce physician travel time and permit full use of the hospitals' manpower and technical resources without having to admit patients as bed patients;

"3. redefining many health service tasks so that lesser trained personnel can take them on. . . .;

"4. permitting nurses to make house calls in medically supervised home health programs;

"5. creating closer linkages between related hospitals to permit grouping of maternity, open heart surgery, and other specialized low use services at fewer larger hospitals;

"6. encouraging all families to develop more efficient medical care habits by identifying with one nearby physician group for provision and supervision of all needed health services.

"Other ideas were mentioned less frequently: automation and computation, self-help units in hospitals, intensified health education, multiphasic screening, etc. No one in the group suggested any lengthening of the work week. . . .

"Interestingly enough, many of the doctors whom I asked felt that the process of reorganizing to reduce manpower could produce improved quality with fewer health personnel. . . .

"I ... asked one last question: suppose the great national crisis was not a long world war, but the spiralling cost of medical and hospital services and the many unmet health nceds right in your own region, the deaths and suffering that could be avoided by expanded and improved health service. . . . Could you deliver? I wish I didn't have to report that most of my group doubted that it would be possible, under present circumstances, to achieve the degree of commitment and cooperation that would produce results. At least, as a number said, 'not in my lifetime." "

Id. at $65-66$.

${ }^{23}$ See the discussion in note 17 supra.

${ }^{24}$ Approximately $15 \%$ of the physicians practicing in the United States are now members of medieal groups, and the percentage is growing slowly but steadily each year. 
the large institutional health complex, the progress in this area has been painfully slow. Health manpower recruitment and coordination, which could help solve many of the current delivery problems, continue to be frustrated.

\section{B. Structure of the Industry}

Optimal utilization of personnel as well as provision of perquisites to attract personnel are in part functions of the size and scope of the organizations that deliver health care services. Large-scale units for delivery of health care are few, scattered, and often inaccessible. ${ }^{25}$ Optimal utilization requires more than just freedom from legal constaints which prohibit matching skills with tasks but also embraces the notion that larger organizations provide opportunities for such optimal utilization that smaller units of care do not. The solo practitioner does not have much opportunity to match tasks with demonstrated skills if he has only one nurse.

The archaic structure of the industry has led some to suggest that the alleged manpower shortages are chimerical. It is argued that if the industry were characterized by large health care organizations with the freedom to employ and utilize personnel subject only to responsibility for the "outcomes" of health care services, and if such organizations exerted market pressures upon specialty training institutions and programs to align the supply of specialists with the demand, shortages might disappear. ${ }^{26}$ This analysis, while profound and largely supportable, neglects one crucial factor-health care providers themselves are not responsive to market pressures exerted by consumers, because demand levels are not determined by consumers but by physicians (and hospitals and other practitioners to a lesser extent). ${ }^{27}$ Health care providers dictate health care needs to a complaisant public. This is a critical point to make but difficult to comprehend despite its apparent simplicity. Health care services differ from almost all other services in that the provider controls the spigot. It is the physician who decides what and how much is needed, when it stops hurting, and how much it costs to make it stop. The argument that manpower shortages would be alleviated if personnel were utilized differently might be tenable, however, if the incentives of the providers were aligned

\footnotetext{
${ }^{25}$ For purposes of this article a major distinction is drawn between large health care organizations and group practices. Naturally the line must be drawn somewhat arbitrarily. Examples of large health care organizations include the Mayo Clinic in Rochester, Minnesota, and the Kaiser-Permanente group with facilties in a number of cities.

${ }^{20}$ See, e.g., $x$ AMA, Distribution of Physicians, Hospitals, and Hospital Beds in the UntTed States, ig66 (ig67); Bureau of Heazth Manpower, Health Manpower, Perspective ig67 (Public Health Service Pub. No. $x 667$, 1967 ).

${ }^{27}$ Of course to say that physicians determine demand is not to say that physicians can set any price for their services. While they have great latitude in setting price levels, various constraints do exist. Should prices become prohibitive, patients will defer, if not neglect, health care needs. Furthermore, the Social Security Administration is constantly revising Medicare and Medicaid reimbursement formulae in an attempt to control price escalation. See, e.g., the Health Cost Effectiveness Amendments inciuded in the 1971 Amendments to the Social Security Act now pending before Congress. H.R. I, 92d Cong., Ist Sess. $\$ \$ 22 I-43$ (as passed by the House, June 22, I97I).
} 
with those of the consumer. The nature of such incentives is determined in large part by the financing mechanisms used for health care services.

\section{Financing Mechanisms}

The price at which and manner in which something is bought influence the structure and capacity of the industry supplying it. The health care industry offers ample evidence of this proposition. A fee-for-service system focuses upon payment for health services, not maintenance of health. Thus services, the need for which is determined by the providers of those services, are continuously bought by users. This induces inelasticity in demand and leads to increases in cost.

The federal government, principally through the medium of Medicare and Medicaid, now purchases approximately twenty-five per cent of the health care bought in the United States. ${ }^{28}$ Under Medicare and Medicaid the fee-for-service system is not only preserved but buttressed, with physicians being allowed to charge the fees that they collectively deem to be reasonable. ${ }^{20}$ Since providers have no incentive to reduce them, costs have steeply escalated in recent years. ${ }^{30}$

Efficient use of personnel, utilization of medical hardware to reduce labor costs, and relaxation of entry barriers to paraprofessionals depend upon a competitive market for health care. The current system is monopolistic. The perpetuation of the fee-for-service financing system has precluded market influences which, among other things, would ease manpower shortages and foster innovative utilization practices. Prepayment, as distinguished from fee-for-service payments, such as would be facilitated by the health maintenance organization option proposed under Medicare, alters the incentives by aligning providers and consumers in the pursuit of a common end-maintenance of health. ${ }^{31}$ A health maintenance organization would not be paid for a unit of service but rather would be paid a lump sum per patient in advance. This prepayment would cover the costs of all necessary health services, including hospitalization. The health maintenance organization option, therefore, has fundamental implications for the structure of the industry by

\footnotetext{
${ }^{28}$ See U.S. Dep't of Health, Education, and Welfare, Social Secunity Administration, Size and Shupe of the Medical Care Dollar (1969).

${ }^{29}$ See, e.g., Social Security Amendments of I965, Pub. I. No. 89-97, tit. I, $\S$ x02(a), 79 Stat. 322 (enacting 42 U.S.C. $\$ 1395 x(v)$ ).

${ }^{30}$ In the past decade consumer medical expenditures have more than doubled, while disposable income has increased only 10\%. From 1965 to 1968 medical care prices increased at an annual ratc of $5.8 \%$ compared with a $3.3 \%$ increased for all consumer items. Size and Shape of the Medical Cars Dollan, supra note 28 . See also note 18 supra.

${ }^{31}$ See section 239(a) of the I971 Amendments to the Social Security Act supra note 27. The "health maintenance organization option" provides simply that qualified health maintenance organizations, as defined in the amendments, will be paid by the government for services provided to program eligibles at the rate of $95 \%$ of what the government pays fee-for-service providers in the same geographic locale for comparable populations. Health maintenance organizations must operate on a capitation (so much per head) basis. Such organizations tend to emphasize preventive care. Since profitably and stability tend to be functions of organizational size when the price for a commodity or service is fixed $(95 \%$ of the fee-for-service cost under Medicare), an increase in the size of the units for delivery of health care can be expected when and if health maintenance organizations develop.
} 
virtue of its potential for fostering the evolution of large-scale health care organizations which would have incentives to seek economies of scale and comprehensiveness in the array of services and benefits. ${ }^{32}$

\section{Distribution of Health Care Resources}

Health care resources are poorly distributed. ${ }^{33}$ Restrictions on entry of paraprofessionals, together with excessive stringency in the specification and regulation of practice spheres, aggravates this maldistribution. Recognition must be given to the fact that in a system marked by shortages, the supply will be least in areas least attractive to practitioners; rural areas and low-income pockets in large urban areas suffer the most from distribution patterns. The distributional problem is in part circular. Much of the unattractiveness of underserved areas is attributable to the unreasonable workloads created by manpower shortages. The problem can thus be alleviated in two ways: by modification of licensure barriers to allow entry by paraprofessionals and by change in the law to permit more optimal utilization of currently licensed personnel.

\section{The Quality of Health Care-Regulatory Controls}

Before proceeding to a discussion of proposals for changing current practices, licensure must be viewed in the context of its intended purpose. Licensure is designed to regulate quality of care-but in what way, and how effective is it?

Perhaps the most difficult problem is determining what constitutes "quality" in health care and what measures are essential to ensure this quality, assuming it can be defined. Health care experts find little ground for agreement on what "quality" is;" similar uncertainty exists respecting regulatory mechanisms to measure it.

Conceptually, enforceable controls over the quality of care can be categorized as input measures, process or internal measures, and outcome measures. These measures are shown schematically in Figure $x$. Licensure is an input measure under this schema. As such it is subject to the same infirmities as other input measuresmost, at best, are conjectures about what kinds of inputs into a black box will

\footnotetext{
${ }^{32}$ Economies of scale are as possible in health care as they are in franchising generally. If each "Holiday Inn" had to purchase building materials and supplies separately, each motel unit would undoubtedly cost more. An exhaustive analysis of prepayment of health care services as a means of influencing organizational change in the health care system has been undertaken in Note, The Role of Prepaid Group Practice in Relieving the Medical Care Crisis, 84 Harv. L. Rev. 887 (I97I). A section of that article is devoted to the health maintenance organization development.

${ }^{33}$ For example, only $12 \%$ of all physicians and $18 \%$ of all nurses practice in rural areas-where $30 \%$ of the population is. Specialists are even more scarce in these areas; only $8 \%$ of all pediatricians and $4 \%$ of all psychiatrists practice outside urban areas.

B4 One of the most informative general articles on the question of quality is Donabedian, Measurement of Quality in Health Care, in 2 Nat's Heasth ForUm, Action Proposals aNd Discussions i95236 (1968).
} 
yield good results. When a more direct means of assessing health care outcomes is developed, the utility of their continued use is called into question. Such outcome measures are currently under development. ${ }^{35}$

The confluence of two courses of development forms the basis for a new approach to licensure: first, the growing conviction (and evidence) that input and process measures do not bear a sufficient or defensible relationship to the quality of health care, and second, the imperatives that derive from investing organizations, as opposed to individuals, with the responsibility for providing health care.

\section{A. Input, Process, and Outcome Measures}

To use a homely example, most of us judge a restaurant on the basis of the taste and the quality of the food served. Seldom, except for reasons for epicure, do we inquire as to the chef's lineage and education. Less often do we personally visit the kitchen to inspect the ovens and utensils. The quality of meals and the results of health care are matters of different importance and magnitude, but the analogy is nonetheless instructive. The regulatory measures traditionally employed to control the quality of health care have focused on who renders it, how, and why, more often than on what the results have been.

In defense of input and process measures, it must be acknowledged that assessment of the quality of health services by measuring the outcomes of care is an extraodinarily complex task. Present technology for this purpose is not as sophisticated as the concept. Consequently, reliance upon traditional measures is at least explainable if it is assumed that rational outcome measures have not been available. Even without such alternative measures, however, the question still arises as to whether licensure is defensible without demonstrable evidence of its relationship to the quality of care.

Early licensure laws were the product of concern, if not alarm, on the part of legislatures called to witness egregious quackery. ${ }^{36}$ But as licensure laws have evolved, the licensure system has grown cumbersome and outmoded. Its historic course resembles on ecological remedy designed to cure a specific problem only to become one-a species of rodent imported to curb the rapacious behavior of another pest only to succeed to the extent of setting off another imbalance. Licensure would likely fall of its own weight except for a reverence for professionalism which proves a paraphrase of Veblen's maxim: nothing defends itself more vigorously than a health care profession threatened with the loss of its licensure statute.

Total abrogation of licensure laws may be abstractly possible, but political verities may make a different approach more feasible. Some acceptable substitute

\footnotetext{
${ }^{35}$ See, e.g., Sanazaro \& Williamson, End Results of Patient Care: A Provisional Classification Based on Reports by Internists, 6 MEd. CARE 123 (I968); Department of Medical Care, Johns Hopkins University, Prognostic Epidemiology: Concept, Process and Product (unpublished paper). See also Ourcomss of HeALTh Care-A COMPENSATION SXSTEM For MEdicai InJuRIEs (conference transcript, forthcoming) [hereinafter cited as Outcomes of Heslth Care].

${ }^{86}$ See note 5 supra.
} 
to measure quality must be developed to provide the rationale for the elimination or at least the modification of licensure. There are two possible measures, each complementing the other. First, a system of quantitative measurement must be developed to provide indices for measuring actual health care outcomes against scientifically derived standards of outcomes. ${ }^{37}$ When results are plotted against such standards, ground would exist for action against the organizations and/or practitioners involved in the provision of the care. A second measure must incorporate the technology of the first. Currently, the findings of medical malpractice litigation serve as outcome measures. ${ }^{38}$ They will continue to serve, but a compensation system for medical injuries premised upon outcome technology as an alternative to the current system may be developed. Certainly, given the random magnanimity of the current system and the cost dimensions, some alternative form of compensation system should evolve. There is much ferment regarding compensation arrangements in the context of automobile accidents. The medical injury problem may provide a more manageable and felicitous focus for testing an experimental compensation system. ${ }^{38}$

Development of the mechanisms to test outcomes may take time, and such mechanisms may not of their own force impel the demise of licensure. The emergence of large health care organizations may, however, hasten the deliverance from licensure with or without development of a reliable outcomes technology.

\section{B. The Trend Towards the Delivery of Care by Organizations}

In I946, 404 groups of physicians practiced medicine in the United States. ${ }^{40}$ By 1969 the number had increased to $6,377^{41}$ The trend is irreversible, especially in view of the increasing complexity of health care services. The projection is for I6,000 groups by 1975 .

The proposed I97I amendments to the Social Security Act would place the government's purchasing power behind large health care organizations referred to in the legislation as health maintenance organizations. ${ }^{42}$ Health maintenance

\footnotetext{
${ }^{37}$ See note 35 supra.

${ }^{38}$ That is, to the extent evidentiary rules permit, a malpractice decision adverse to the health care practitioner and/or institution constitutes a measure of the outcome of litigation. It is an open question how sensitive a measure it is. See Outcomes of Health CARE, supra note 35.

${ }^{30}$ A great deal has been written concerning the substitution of a compensation system for the present tort system of spreading losses caused by automobile accidents. See, e.g., A. EkRENzweig, NeGLigence Withour Faurt (I95I); James, The Columbia Study of Compensation for Automobile Accidents: An Unanswered Challenge, 59 Colum. L. Rev. 408 (1959); R. Keeton \& J. O'Conneli, Bastc PROTECTION For the Traffic Victim (1965).

A similar system for medical injuries is as possible, if not more probable, given the dimensions of current tort litigation for medical malpractice. A compensation system for medical injuries might be a preferable context for experimentation, but little has been written on this question. Cf. Hanson \& Stromberg, Hospital Liability for Negligence, 2 I Hasrıngs L.J. I (1969). See also Ehrenzweig, Compulsory "Hospital-Accident" Insurance: A Needed First Step Toward the Displacement of Liability for Medical Malpractice, 3r U. Chr. L. REv. 279 (I964).

10 See Medical Group News, July 1970, at -.

¿1 See note 22 supra.

${ }^{12}$ H.R. I, supra note $27, \$ 226$.
} 
FIGURE I

\section{Health Care System Quality Controls}

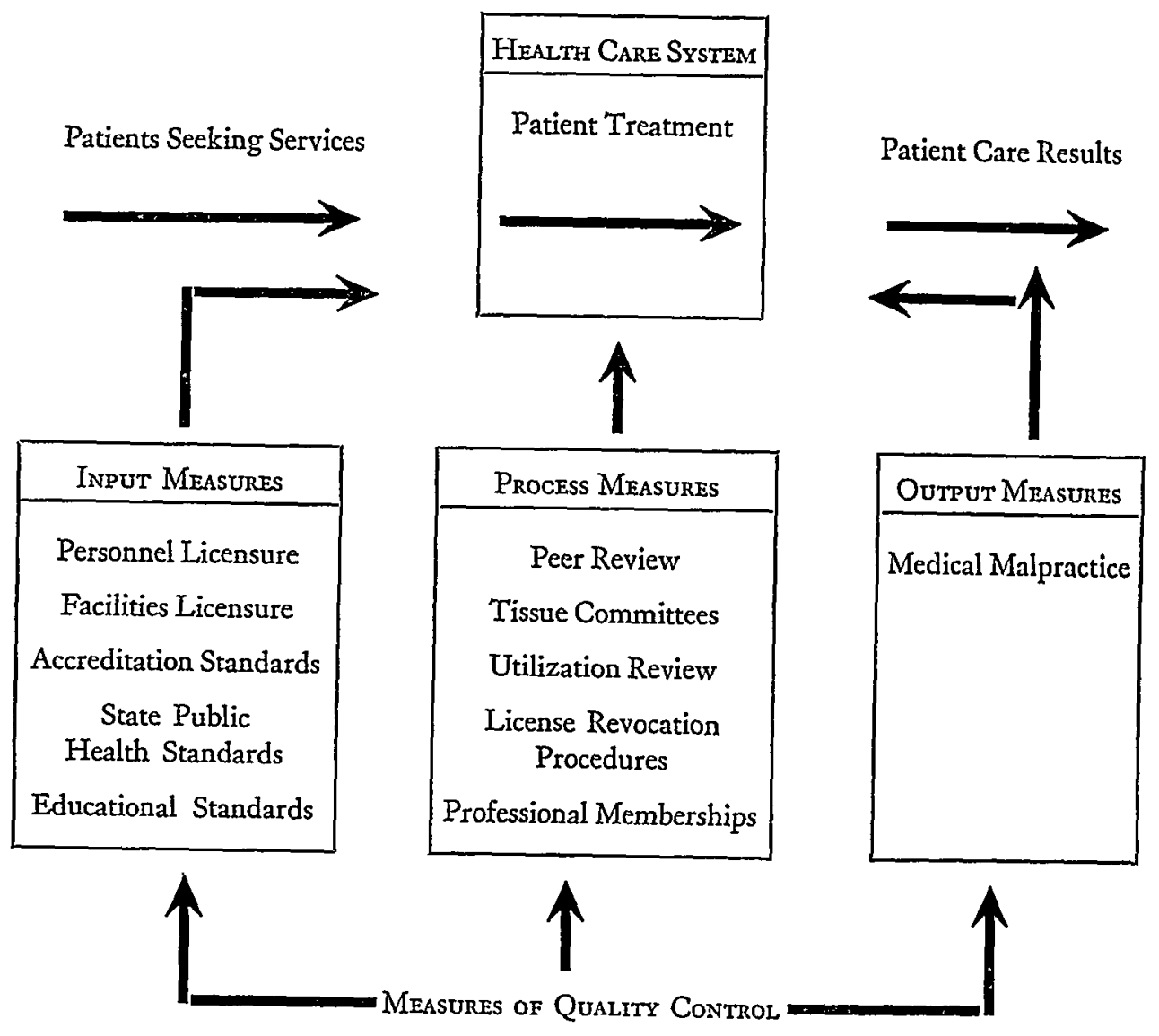

organizations were defined in the proposed amendments as a public or private organization which-

(I) provides, either directly or through arrangement with others, health services to enrollees on a per capita prepayment basis;

(2) provides with respect to enrollees to whom this section applies (through institutions, entities, and persons meeting the applicable requirements of section I86I) all of the services and benefits covered under parts $A$ and $B$ of this title;

(3) provides physicians' services directly through physicians who are either employees or partners of such organization or under an arrangement with an organized group or groups of physicians which is or are reimbursed for services on the basis of an aggregate fixed sum or on a per capita basis;

(4) demonstrates to the satisfaction of the Secretary proof of financial responsibility and proof of capability to provide comprehensive health care services, including institutional services, efficiently, effectively, and economically; 
(5) has enrolled members at least half of whom consist of individuals under age 65;

(6) has arrangements for assuring that the health services required by its members are received promptly and appropriately and that the services that are received measure up to quality standards which it establishes in accordance with regulations; and

( 7 ) has an open enrollment period at least once every two years, under which it accepts eligible persons (as defined under subsection (d)) without underwriting restrictions and on a first-come first-accepted basis up to the limit of its capacity (unless to do so would result in failure to meet the requirement of paragraph $(5)) .43$

Embraced in the definition are many possible organizational patterns including both nonprofit and for-profit corporations. The emergence of health maintenance organizations to provide health care is expected on a broad scale. How soon, and how many, is problematic, but transformation of the organizational characteristics of the health care industry is certain. ${ }^{44}$

Under established tort principles, organizations generally bear the financial responsibility for the deficient performance of their components. The principal defendant in litigation over injuries to a child hit by a truck is the trucking company. Similarly, health care organizations can assume and bear the responsibility for health care services. Assumption of the obligation need not be under statutory compulsion but can arise from both internal pressures from employee-practitioners and the natural evolution of tort law. ${ }^{45}$ Litigation against health care institutions is currently increasing. As illustrated by the Darling case in 1965 and the limiting of charitable immunity, hospitals are more and more frequently the targets of successful malpractice claims. ${ }^{46}$ The same pattern of litigation is likely with respect to new organizational types such as health maintenance organizations.

If organizations bear the burden of control over the quality of care, the demand to relieve such organizations of the constraint of licensure laws which inhibit utilization practices better calculated to produce high quality health care outcomes can be expected. We can pursue the analogy of the trucking company. The company seeks to limit its exposure to claims by employing responsible drivers and by utilizing those drivers commensurate with their ability; a health care organization will possess the same incentives and should possess the same latitude that the trucking company does, except perhaps with respect to physicians, for whom licensure may continue to be necessary. This suggests the outlines of a proposal for a

\footnotetext{
${ }^{43}$ H.R. I, 92d Cong., Ist Sess. $\$ 239$ (a) (as originally introduced).

44 Although it is an encouraging factor in promoting group practice, the health maintenance organization option provided under Medicare is not a sine qua non, since the trend towards organizational development has been apparent in recent years.

${ }^{25}$ Organizational assumption of increased responsibility for tortious conduct is a characteristic of current tort law. There is nothing so unique about health care organizations or practitioners as to justify special treatment of organizational responsibility.

${ }^{d a}$ See Darling v. Charleston Community Memorial Hospital, 33 Ill. 2d 326, 2Ir N.E.2d 253 (I965).
} 
radical modification of licensure law. Before examining this proposal, however, we should consider some of the other suggestions for change that have been made.

\section{Proposals}

\section{A. Maintenance of the Status Quo}

Those who believe that legislative change is unnecessary argue that the law now has sufficient Alexibility to accomodate the entry of new paramedical personnel and to allow delegation of duties by licensed practitioners to allied health professionals. Many proponents of this view believe that the shortage of health care personnel can be solved by augmenting the numbers of practitioners in existing licensed professions.

Perhaps one advantage to this position is that attention is not called to the deviations from prevailing law in current utilization practices. Of course, there is substance to the argument that the exposure to liability for performance of tasks simply on the basis of a lack of licensure authorization is not extreme. The incidence of claims for malpractice and disciplinary proceedings arising principally from violation of licensure statutes is probably very low given the volume of health care services delivered. But the paucity of claims premised on illegal activity and the failure of disciplinary boards to take cognizance of licensure violations are questionable grounds for satisfaction with the current system. Maintaining the status quo may in reality serve to aggravate the utilization problems which have become apparent. It is true that there is some flexibility in current law by virtue of a general delegatory authority under common law, but the precise nature and extent of this authority, in the absence of statute, is left to be determined by litigation. ${ }^{47} \mathrm{~A}$ more satisfactory resolution of the very real problems of practitioner shortages and permissible utilization practices seems neceessary.

\footnotetext{
${ }^{47}$ See Magit v. Board of Medical Examiners, 57 Cal. 2d 74, 366 P.2d 8r6, I7 Cal. Rptr. 488 (Ig6r). Three persons, trained as physicians but unlicensed in California to practice medicine, were employed by the defendant doctor to administer anesthetics under his direction and supervision. The defendant, however, was found guilty of violating section 2392 of the Business and Professions Code. The court said:

'Under some circumstances, persons not licensed to practice medicine in California may legally perform some medical acts, including the administration of anesthetics. For example, sections 2I 47-21 47.6 of the Business and Professions Code permit certain persons engaged in medical study and teaching at approved hospitals to perform acts which constitute treatment of the sick, but no such exemption is applicable to the activities of Rios, Celori, and Ozbey at the Doctors Hospital, which concedely was not approved for the training of students or interns. Another example is found in Chalmers-Francis v. Nelson (1936) 6 Cal. 2d 402, 57 P.2d 1312, where it was held that a licensed registered nurse should not be restrained from administering general anesthetics in connection with operations under the immediate direction and supervision of the operating surgeon and his assistants."

Id. at $82-83,366$ P.2d at $8 \mathrm{Ig}$, I7 Cal. Rptr. at $49 \mathrm{r}$.

"In Lesnik and Anderson, Nursing Practice and the Law (2d ed. 1955) pp. 277-279, it is said that nurses perform many functions that are medical acts, and, in the absence of statute, custom and usage generally will control the nature and scope of medical acts performed by them.
} 


\section{B. Expanding the Licensure Scheme}

If a new health manpower category is identified, a specific licensure statute can be sought to afford recognition to its members. Essentially the same process can be implemented to expand or contract the functions defined by existing licensure laws. ${ }^{48}$ There is little doubt that this procedure has some utility. Basically, it is

Among the minimum requirements for a nurse's authority to perform such acts are that she proceed under the order and direction or supervision of a licensed physician and that she comprehend the cause and effect of the order."

Id. at 83 n.5, 366 P.2d at 820 n.5, I7 Cal. Rptr. at 492 n.5.

"In the absence of some statutory basis for an exception, such as those with respect to nurses and persons engaged in medical study or teaching, one who is not licensed to practice medicine or surgery cannot legally perform acts which are medical or surgical in character, and supervision does not relieve an unauthorized person from penal liability for the violation of statutes which, like section $2 \mathrm{I} 4 \mathrm{I}$ of the code, prohibit the unlicensed practice of medicine. (State v. Cornelius, 200 Iowa 309, 204 N.W. 222, 223; State ex rel. Collet v. Scopel (Mo.) 316 S.W.2d 515, 519; State v. Young (Mo. App.) 215 S.W. 499, 50I; State v. Paul, 56 Neb. 369, 76 N.W. 86x, 862; Gobin v. State, 9 Okl. Cr. 201, I3I P. 546, 547, 44 L.R.A., N.S., 1089.)"

Id. at 84,366 P.2d at 820 , I7 Cal. Rptr. at 492 .

"Likewise, a licensed practitioner who aids and abets the performance of medical or surgical acts by an unauthorized person is guilty of unprofessional conduct under section 2392 of the code even though the acts are done under his immediate direction and supervision. (Newhouse v. Board of Osteopathic Examiners, 159 Cal. App. 2d 728, 732, 324 P.2d 687 [license of osteopathic physician and surgeon suspended for 30 days because he directed a chiropractor to insert sutures in the body of a patient under his supervision]; Garfield v. Board of Medical Examiners, 99 Cal. App. 2d 219, 230, 22I P.2d 705 [licensed physician operating a hospital held subject to discipline because he employed physicians licensed in other states but not in California to practice medicine under supervision in the hospital].) It should be noted that in the Garfield case the physicians, while not licensed in California, were graduates of approved medical schools, had served internships in approved hospitals, and were eligible to be licensed in this state on a reciprocity basis. (99 Cal. App. 2d at p. 222, 221 P.2d 707.) The fact that, as is also true in the present case, the unlicensed physicians had training enabling them to practice competently did not exculpate the physician who aided them in practicing. This is the necessary result of our statutory system which, in order to assure the protection of the public, requires that a person's competency be determined by the state and evidenced by a license."

Id. at $84-85,366$ P.2d at 820-2I, 17 Cal. Rptr. at $492-93$.

The Magit case is still good law in California. See O'Reilly v. Board of Medical Examiners, 66 Cal. $2 d$ 38x, 426 P.2d x67, 58 Cal. Rptr. 7 (1967). Cf. People v. Albert, 358 Mich. 647 , 1or N.W.2d 378 (1960). Defendant employed a chiropodist to assist him in performing a mastectomy. The court held that no crime had been committed, because the acts of the assistant were such as could have been performed by an ordinary nurse and the assistant was at all times under the direction and supervision of the defendant.

In addition, the following cases involve suits in which the liability of the doctor was predicated upon the negligence of his assistants or subordinates. However, the cases all seem to involve acts which were within the authority granted to the person performing them by virtue of his license as a nurse or other medical assistant. The doctor's liability was based on theories of respondeat superior, but the acts which be directed the other parties to perform in these cases did not seem to be direct delegations of medical practice. See Mazer v. Lipshutz, 3I F.R.D. I23 (E.D. Pa. 1962); Natanson v. Kline, I86 Kan. 393, 350 P.2d I093 (1960); McElroy v. Employers' Liability Assurance Corp., I63 F. Supp. 193 (W.D. Ark. I958); Thompson v. Lillehei, I64 F. Supp. $7 x 6$ (D. Minn. 1958); Voss v. Bridwell, I88 Kan. 643, ${ }_{364}$ P.2d 955 (196r); McKinney v. Tromly, 386 S.W.2d 564 (Tex. Civ. App. 1964); Minogue v. Rutland Hospital, Inc., II9 Ver. 336, I25 A.2d 796 (1956); Huss v. Vande Hey, 29 Wis. 2d 34, 138 N.W.2d I92 (I965); Honeywell v. Rogers, 25x F. Supp. 84x (W.D. Pa. I966); Buzan v. Mercy Hospital, Inc., 203 So. 2d II (Florida 1967); Monk v. Doctors Hospital, 403 F.2d 580 (D.C. Cir. I968); Levett v. Etkind, 158 Conn. 567, 265 A.2d 70 (1969); Stone v. Sisters of Charity, 2 Wash. App. 607, 469 P.2d 229 (1970).

"Although the scope of authority for health care practitioner groups can, of course, be changed 
the way in which new categories have been legally recognized since physicians were first licensed in this country. ${ }^{40}$ The question to be asked is, Has this procedure been adequate? There are grounds for arguing that it has not. The rationale advanced by those who believe the procedure is deficient can be concisely stated: manpower shortages can be demonstrated, and studies have shown that the duties that can be capably performed by certain health care practitioners are not necessarily those granted by statute and custom. ${ }^{50}$ To the extent that its rigidity prevents optimal utilization of personnel, the law prohibits practices which could alleviate the shortages and possibly lead to more economical, comprehensive, and highquality health care.

\section{Certification of Paramedicals}

Proponents of a certification procedure suggest an expansion of the rule-

by amendments, it seldom happens. The type of amendments most commonly enacted simply add a new licensure category to the existing set of statutes. In Minnesota, for example, no ccrtification procedure exists-all health care professionals are licensed pursuant to separate licensing provisions. This development, with years of original enactment for each health care profession, took place as follows:

\section{Profession}

Dentists and dental hygienists

Pharmacists

Physicians, surgeons, and osteopaths

Registered nurses

Optometrists

Chiropractors

Practical nurses

Physical Therapists

Psychologists

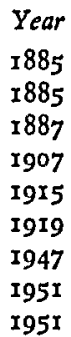

40 The degree of professional association national activity is related to the spread of licensure. Medicine was the first of the recognized health professions to achieve licensure in all states. It was followed by pharmacy and dentistry and still later by optometry. Chiropractic has never been licensed in all states. The following table indicates the years of enactment and the years of nationalization of association:

$\begin{array}{lcc}\text { Organized } & \text { Licensed in } \\ \text { Nationally } & \text { All States } \\ \text { Medicine } & 1847 & 1915 \\ \text { Pharmacy } & 1852 & 1935 \\ \text { Dentistry } & 1859 & 1935 \\ \text { Optometry } & 1897 & 1939 \\ \text { Chiropractic } & 1910 & \times\end{array}$

50 There is of course some degree of deviancy between actual task performance by a licensed health care professional and the task boundaries codified by licensure statutes as modified by custom. The argument that there is some flexibility, however, is two-edged. While it is undoubtedly truc that some licensure statutes do not fix the absolute limits of legitimate performance, such statutes leave the placement of boundaries so much in doubt that the performance of tasks beyond those clearly within the legal competence of a practitioner must be assessed on a case-by-case basis. Conversely, where the boundaries are clearly delineated they are so often unrealistically drawn that their breach is the rule and not the exception. The danger is, of course, that the breach can result in litigation. A typical example is Barber v. Reinking, 68 Wash. 2d 139, $4 \mathrm{rI}$ P.2d 86I (I966), where a practical nurse performed a simple innoculation and upon a complication was, along with the delegating physician, subjected to a malpractice suit. Their defense was that the performance of the task by the nurse was a matter of custom. The licensure statute, however, contained an express prohibition against innoculation by practical nurses. 
making power of licensure boards and agencies by vesting in them the authority to certify new paramedical types and to adjust the functional spheres for each group under their jurisdiction. One significant advantage of this proposal is that it may facilitate quicker and more flexible action than is possible through legislation because an administrative board may meet at will whereas a legislature may not. Another advantage may be that boards comprised of health care experts are presumably better able than other authorities to tailor actions to meet specific needs. Finally, because a board's power could be broad, new types of manpower could be rapidly integrated into the industry.

There are various disadvantages to this approach. Boards and agencies are usually composed of professionals from the general category for which licensure authority is granted by statute. ${ }^{51}$ For example, nurses are usually responsible for deciding whether an auxiliary category for nursing should be established, and so on. These professional groups may not be willing to create new categories which might pose a threat to the established profession. If each operative board or agency were to be independently granted this additional power, opportunities for intercategory adjustment and shifting of functions would be minimal, at best. For example, even if the board for nurses were given the power to modify the functions to be performed by nurses, its action would be neither binding on nor applicable to other personnel outside the jurisdiction of that board. Finally, certification may actually be nothing more than a form of licensure. Even though it may be a more responsive tool and a more flexible way to deal with emerging paramedical groups, a certification scheme would not necessarily reduce-and might in fact increase-fragmentation in the utilization of health care personnel. ${ }^{52}$

\footnotetext{
${ }^{61}$ For a convincing demonstration of the degree to which health care licensing boards are comprised of or controlled by the very professionals under regulation, see Akers, supra note 7 .

${ }^{53}$ Professor Friedman provides nice definitions of the three terms used (often too interchangeably) to describe the process of formal legitimation of a health care professional group: registration, certification, and licensure. The terms are generally used in this article as defined by Professor Friedman:

"It is important to distinguish three different levels of control: first, registration; second, certification; third, licensing.

"By registration, I mean an arrangement under which individuals are required to list their names in some official register if they engage in certain kinds of activities. There is no provision for denying the right to engage in the activity to anyone who is willing to list his name. He may be charged a fee, either as a registration fee or as a scheme of taxation.

"The second level is certification. The governmental agency may certify that an individual has certain skills but may not prevent, in any way, the practice of any occupation using these skills by people who do not have such a certificate. One example is accountancy. In most states, anybody can be an accountant, whether he is a certified public accountant or not, but only those people who have passed a particular test can put the title CPA after their names or can put a sign in their offices saying they are certified public accountants. Certification is is frequently only an intermediate stage. In many stages, there has been a tendency to restrict an increasing range of activities to certified public accountants. With respect to such activities there is licensure, not certification. In some states, 'architect' is a title which can be used only by those who have passed a specified examination. This is certification. It does not prevent anyone else from going into the business of advising people for a fee how to build houses.
}

"The third stage is licensing proper. This is an arrangement under which one must obtain 


\section{Enactment of Specific and General Delegatory Statutes}

Under decisional law, physicians and (to a lesser extent) other health care practitioners enjoy a general power of delegation, exercisable, however, only if direction and supervision are furnished by the delegating professional. ${ }^{53}$ This power is not easily defined, and numerous questions can be raised which may require clarification through litigation. Arizona, Colorado, Kansas, and Oklahoma have attempted to deal with this problem by enacting general delegatory statutes. ${ }^{\text {of }}$ These statutes have simply codified the right presumed to be available to the physician to delegate health care functions under his direction and supervision. This type of statute is useful because it may vindicate the physician when the delegation of duties results in litigation. Such a statute may also serve to encourage delegation of duties to licensed or unlicensed personnel by explicitly sanctioning the practice.

If a general delegatory statute is not enacted, a specific type of delegatory power may be made available by different means. Thus, rather than a general power of delegation, the physician might be given the express power of delegating to only one other type of health care professional, such as a nurse or physician's assistant. Such a statute is necessarily more limited than a general delegatory statute, and its enactment might raise the question of whether specifically authorizing delegation to one type of auxiliary practitioner implies that delegation to others is not permissible. ${ }^{65}$ Since this approach to the licensure problem is becoming prevalent, it must be subjected to a more critical analysis. ${ }^{56}$

Perhaps the best discussion of delegatory statutes is contained in a recent article on health manpower problems. ${ }^{57}$ The authors accurately point out some of the limitations in delegation statutes: (a) vague guidelines for delegation; (b) use of swampy terms like "under the supervision and control"; and (c) limitation of delegatees to members of specified professions, either licensed or unlicensed. To remedy these problems the authors suggest that delegations might be allowed only as to persons approved by the appropriate state board of medical examiners

a license from a recognized authority in order to engage in the occupation. The licensc is more than a formality. It requires some demonstration of competence . . . , and anyone who does not have a license is not authorized to practice and is subject to a fine or a jail sentence if he does engage in practice."

See Friedman, supra note I, at $144-45$.

${ }^{68}$ See note 47 supra.

Et See ARIz. Rev. Stat. ANn. \$32-I42I(6) (Supp. I970); Colo. Rev. Stat. \$9I-r-6(3)(m) (1963); Kan. Stat. ANN. $\$ 65-2872$ (g) (I964); OkLA. Stat. ANn. tit. 59, $\$ 492$ (Supp. 1970).

${ }^{6}$ The argument is, of course, a simple one. If the statute specifies only one subprofessional group for a permissible delegation, then, by old dogma, all others are excluded.

${ }^{68}$ State legislatures in North Carolina, West Virginia, Minnesota, Utah, Washington, and Wisconsin have either recently enacted statutes or are considering bills on this subject. Conversation between the author and Dr. Douglas Fenderson, National Center for Health Services Research and Development.

${ }^{57}$ Forgotson, Bradley \& Ballenger, Health Services for the Poor-The Manpoiver Problems: Innovation and the Law, I970 Wisc. L. REv. 756. 
pursuant to regulations developed by such board. ${ }^{58}$ Control over delegations would therefore be exercised through a two-stage process: first, the board would establish general usage guidelines through regulations; and second, the board would invest the delegating physician with the responsibility for supervision. The physician would therefore be answerable for the negligent conduct of delegatees under accepted principles of vicarious liability. ${ }^{59}$ The authors consequently recognize some of the problems inherent in the delegation approach ${ }^{60}$ but suggest that "[o]nly time and experience can produce answers . . . in jurisdictions adopting this approach." ${ }^{\text {1 } 1}$

A variation of the above approach is also presented. This alternative places substantially greater reliance upon the delegating physician.

Under such a scheme, it would be solely the physician's responsibility to determine that persons to whom he delegates are qualified by formal or informal training and experience to perform the functions delegated. Primary reliance for the public's protection would be placed on: (x) the physician's ethical and professional judgment; (2) the deterrent effect of the malpractice risk attending the use of unqualified personnel; and (3) supervision by physicians' or hospitals' malpractice insurers. ${ }^{62}$

Generally, there are advantages to these proposals: greater flexibility; protection for the physician; encouragement to the physician to delegate; legal recogni-

\footnotetext{
${ }^{68}$ Id. at $776-77$.

${ }^{60}$ The authors also speculate-with respect to malpractice-that an assistant delegated duties by a physician would be held to the same standard of care as would a physician, since the assistant would be performing service tasks traditionally undertaken by the physician. Id. at 779 .

${ }^{\circ 0} \mathrm{~A}$ laundry list of other unresolved issues is included in their article:

"(I) What are some criteria which might be used to evaluate applicants who have not graduated from a formal program?

(2) What types of existing office workers and assistants, other than gradautes of physician's assistant programs, should or could seek approval under such a statute?

(3) Would such a statute permit foreign trained physicians who failed to qualify for licensure to practice under very attenuated supervision?

(4) Is there any given act, task, or function which is not delegable under any circumstances to any assistant, regardless of a physician's direction and supervision, and against which a physician should be forewarned?

(5) Should it be possible to approve a physician's assistant if he is to be employed by a hospital? Does this open the door to allowing hospitals to practice medicine?

(6) Is there too much specificity in wording such as 'direct supervision and control' and if so, would more general wording such as 'direction and supervision' by the physician be any better?

(7) The health field as a license-oriented one, and a certain amount of status accrues with licensure. Is it wise to deprive the new paramedical practitioners of the traditional mode of recognition, especially when this scheme otherwise resembles licensure (i.e., approval, possibility that this approval will be revoked, possibility that it will in fact later be necessary to define a scope of practice, at least insofar as saying what is not delegable)?"
}

Id. at 779 .

${ }^{61}$ Id.

${ }^{62}$ Id. at 780. The scheme is attributed to Professor Clark C. Havighurst of the Duke University School of Law. Professor Havighurst would also accept some administrative oversight of delegation practices, implemented by a power to issue cease and desist orders where unsafe practices were found to exist. See id. See also Havighurst, Licensure and Its Alternatives, in Proceedings of the 3D ANNuAL Duke Conference on Physician's Assistants i2I (I970). 
tion for a common practice; and so forth. There are, however, significant disadvantages. If a delegatory statute is general, authorizing delegation to any other practitioner (licensed or unlicensed), it accomplishes little more than the common law authorization of delegation except to relieve the physician of anxiety and perhaps to encourage delegation to some extent. On the other hand, if the statute is specific as to the delegatee (for example, "to a physician's assistant"), the validity of delegations to persons other than those enumerated is called into question, and this could result in a possible contraction of the common law delegation authority. Definitional problems also arise if delegation is permitted only to a limited group. What is meant by "physician's assistant"? Does this term refer to a generic category of practitioners or to a specific type of practitioner?

The proposals are further deficient in that the authorization is limited to onehalf of the delegating equation-the physician. A delegatory statute, while perhaps only codifying general common law delegatory power, does explicitly insulate the physician making the delegation if the controls, both explicit and implicit in the statute, are properly honored. But the legal status of the delegatee is not clarified. This is true both as to licensed personnel-since occasions may arise when the task delegated falls without the scope of practice for the given practitioner-and the unlicensed paraprofessional such as a physician's assistant, since ostensibly no health care services may be performed by unlicensed personnel. This problem may be more apparent than real, however, since ability to accept a delegation can be implied from the law authorizing it.

Another dimension to the problem is that delegation statutes operate only to legitimate delegations to practitioners who are dependent upon the physician. In dependent or semi-independent practitioners such as pediatric nurse practitioners, physical therapists, and, in some instances, emerging types such as the child health associate $^{63}$ may require more explicit exemption from medical practice statutes since they do not function exclusively under the physician's supervising shadow. ${ }^{04}$

A final and perhaps most serious difficulty with the approach of sanctioning physician delegation is that no matter how the delegatory statute is phrased, an incentive inevitably arises to clarify the legal status of the delegatee group through the traditional mechanism of licensure. Thus, while the salutary objective of affording the physician some relief from his anxieties about delegation is achieved, the risk is run that a new category or categories of personnel will ultimately be circumscribed by "licensure walls." Naturally, it can properly be argued that a certification mechanism other than licensure could be used to clarify the delegatees' role. While certification would probably be preferable to licensure for reasons already articulated, the practice still falls short of reducing fragmentation since the likely recipient of certification authority is the board of medical examiners. (Certainly this is evident form existing and proposed delegation statutes.) Thus,

\footnotetext{
${ }^{\text {os }}$ Colo. Rev. Stat. $\$ 9 \mathrm{x}-\mathrm{x} 0-\mathrm{I}$ (Permanent Cumulative Supp. 1969).

${ }^{6 s}$ This point is expressly acknowledged in Forgotson, Bradley \& Ballenger, supra note 57, at 779.
} 
while another licensure statute may have been headed off, delegatee groups will find themselves in the same camp and wholly subject to the "delegatory imagination" of the physician. This danger is manifestly more clear with the second approach to delegation outlined above which vests substantial supervisory authority in the physician. ${ }^{65}$

To summarize: Delegation is a useful but limited device. It should be utilized only if it is recognized as but a partial remedy and only if it is reasonably certain that its disadvantages can be overcome. This can be done by utilizing the mechanism only in combination with other proposals yet to be discussed.

\section{E. Establishment of a Health Manpower Committee or Board}

This proposal is an expansion of the proposal to certify paramedical personnel. It calls for establishing a health manpower committee or board consisting of representatives of all the principal categories of personnel and perhaps lay representatives as well. It overcomes the disadvantages of broadening the power of the various separate licensure boards to certify health care personnel because it would permit more effective intercategory coordination and could thus better facilitate optimal personnel utilization. ${ }^{68}$

There are basically two types of organizations which could be established, a committee or a board. The differences (although not necessarily the terms) are important. A committee might have only advisory authority-that is, it might be empowered only to review proposals for certification of new auxiliary classifications and amendments to present law and make recommendations for action to the various independent boards or agencies possessing certification authority or to the legislature. A board, on the other hand, might be given exclusive certification authority by the legislature. A committee, even without final authority, would be able to deal effectively with gaps and overlaps in functions and might also more objectively judge the necessity for certification of new categories of personnel. A board, however, would possess those advantages as well as the flexibility and responsiveness discussed under the proposal to certify paramedical personnel.

The creation of a committee or board might be effected in several stages. The first stage might be the formation of a coordinating committee with only informal powers. Such a committee could be empowered to make recommendations to licensing boards regarding new categories of personnel and scope of practice changes for licensed personnel. A second stage might couple a freeze on licensure of any new manpower groups with a granting of power to the committee to certify such groups and promulgate regulations concerning utilization in concert with the appropriate licensing boards.

The third and fourth stages might respectively empower the committee (or board) to absorb certain existing licensing board functions and to begin to fuse

\footnotetext{
${ }^{\circ 0}$ See note 62 and accompanying text supra.

${ }^{\circ B}$ See text accompanying note 5 I supra.
} 
scope-of-practice boundaries to eliminate gaps. The committee (or board) might ultimately supplant all licensing boards and establish certification procedures for all health care practitioners, except the physician, while affording representation to all cognizable manpower categories. The advantages of this general scheme are apparent (although no more apparent than the likelihood of vigorous political opposition from entrenched practitioner groups). Further, combining this approach with a general delegatory statute would afford the physician the protection secured by such a statute while cleansing the delegation approach of most of its limitations and dangers.

Aside from engendering controversy, implementation of this scheme is faced with some other problems. First, it will take time. Second, it honors by imitation the notion that licensure and its surrogate forms are vital measures to ensure the quality of care without definitive proof. Third, there is the risk that committees or boards would become calcified and, over time, create fragmentation where flexibility once stood. Fourth, such mechanisms might still be wholly professionally controlled and thus invulnerable to public pressures for changes, except indirectly through the legislative process. Finally, there are grounds for questioning whether boards of this sort would effectively and aggressively develop regulations to guide the performance of practitioners once statutory controls are abrogated. ${ }^{67}$

\section{F. Investing Institutions with Licensure Authority}

A theoretical possibility for the future is based on the evidence that the unit for delivery of medical care is increasing in average size. ${ }^{68}$ Evidence has been cited that care is being rendered more frequently in institutional settings. Advocates of the ensuing proposal point to these trends and suggest that if present manpower licensure, even if modified, is inherently too rigid and unresponsive to meet the increasing needs for manpower in the provision of health care, a more radical solution should be found. The alternative they propose requires shifting some of the control over practitioners currently exerted by the existing licensure scheme to health care institutions and organizations which would be given the responsibility for hiring and utilizing manpower within guidelines established by the state agency that licenses institutions. ${ }^{69}$

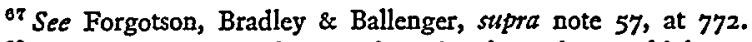

${ }^{68}$ The phenomenon of increasing size is at best a high-grade surmise. No definitive cvidence is available except the documentable trend reflecting an increase in group practice which, to the extent it reduces the numbers of solo practitioners, ineluctably increases the average size of the unit of care.

${ }^{\circ 0}$ Unlike personnel licensure, licensing of hospitals is a recent development. At the end of World War II fewer than a dozen states had comprehensive licensing laws, and these in fact were often just "paper" laws. The principal breakthrough came with the Hill-Burton Hospital Survey and Construction Act of 1946. By I954, thirty-eight states had laws licensing maternity sections of hospitals. This pioneering is still apparent in the strong emphasis on maternity Icgulations in many state licensing programs.

Although the Hill-Burton law did not explicitly require states to enact licensing laws, it did require them to provide minimum standards of maintenance and operation for hospitals built with the help of Hill-Burton funds. Section 2 of the Hospital Survey and Construction Act provided:
} 
There are, of course, variations on this theme. One such variation contemplates establishing job descriptions for various positions within the institution. Professor Nathan Hershey describes it this way:

The state hospital licensing agency could establish, with the advice of experts in the health care field, job descriptions for various hospital positions and establish qualifications in terms of education and experience for individuals who would hold these posts. Administrators certainly recognize the fact that although a professional nurse is licensed, her license does not automatically indicate which positions within the hospital she is qualified to fill. Individuals, because of their personal attainment, are selected to fill specific posts. Educational qualifications, based on both formal and in-service programs, along with prior job experience determine if and how personnel should be employed. ${ }^{70}$

One distinct advantage of this scheme is that it would afford the institutional employer wide latitude in utilizing personnel, subject only to the job descriptions. Presumably, it would allow the flexible use of unlicensed manpower in certain approved jobs.

The proposal is not without difficulties. Some of the questions that can logically be raised are these: (a) How would the scheme affect utilization of institutionbased personnel by independent physicians who presumably would bear no responsibility for their employment and utilization? (b) The scheme presents a solution for institutions, but does it offer any solutions to extrainstitutional utilization of personnel, such as physician practices, except perhaps in those instances where a physician group practice may have achieved institutional status? (c) AIthough purporting to offer a solution to the rigidities of licensure, does not the scheme reintroduce inflexibility at a different level? That is, to the extent that job descriptions become fixed, the functional scope written into the job description becomes limiting and thus may become a constraint to utilization. (d) Is a job description developed in one institution readily transferable to another?

Another variation of this proposal constitutes a rather different and distinct

"If any state, prior to July $\mathrm{x}$, $\mathrm{I948}$, has not enacted legislation providing that compliance with minimum standards of maintenance and operation shall be required . . such State shall not be entitled to further allotments ...."

ch. 958 , 6o Stat. 1044 (r946).

Four years later the 1950 amendments to the Social Security Act provided that any state using federal matching funds to pay for care in public or private institutions for welfare recipients must designate an authority "which shall be responsible for establishing and maintaining standards for such institutions." Social Security Act Amendments of 1950, ch. 809 , tit. III, $\S 30 \mathrm{x}(\mathrm{b}), 6_{4}$ Stat. 548 . Several states had to adopt or amend hospital licensing laws to qualify for these funds. In time, nearly every state had some sort of hospital licensing program. The literature on hospital licensure is extremely sparse. Some articles available include H. Fry, The Operation of State Hospital Planning and Licensure Programs 4 (American Hospital Association Monograph Series No. 15, I965); $\mathrm{K}$. Taylor \& D. Donald, A Comparative Study of Hospital Licensure Regulations (I957). This latter study compares state licensing provisions with earlier ACS standards. See also 2 W. McNERNEY ET al., Hospital aNd Medical Economics (I962); SoMers, supra note 8, at 90 n.20.

${ }^{70}$ Hershey, An Alternative to Mandatory Licensure of Health Professionals, Hospital Progress, Mar. 1969 , at $7 \mathrm{I}, 73$. 
approach which, if adopted, would (a) eliminate present rigidities in licensure; $(b)$ provide the basis for optimal employment and utilization of health manpower; and (c) facilitate the desirable, if not essential, organizational transformation in the health care industry which is resulting in the evolution of large health care organizations.

\section{VI}

Conclusion: A New Proposal

In light of the analysis in this paper, it is proposed that statutory licensure laws be amended to repeal licensure restrictions for all health care practitioners other than the physician when such practitioners are employed by health care organizations registered to do business in the state and licensed to provide health care. All practitioners not employed by health care organizations should be required to obtain certificates of practice from a health manpower board consisting of representatives of health professions, with a majority of nonprofessional representation.

Physician licensure should be retained for all physicians who are not affiliated with health care organizations and even for those physicans who are affiliated with such organizations until such time as geographic mobility would not be impeded by unlicensed status. Physician licensure should then be abolished and replaced by a registry scheme administered by a state health manpower board.

Health care organizations would agree to submit to the process and jurisdiction of the state courts as a condition of licensure and would further agree to participate in a statutory compensation system for medical injuries when such a system is developed. Each constituent element of this proposal is discussed below.

\section{A. Repeal of Statutory Licensure Law}

The discussion in this article has revealed that it is not clear that licensure strictures are related to the quality of care; licensure scope-of-practice constraints have precluded optimal utilization of licensed practitioners; entry of new manpower has been blocked by onerous licensure requirements; and professionals have been slow to bring about change, in part due to anticompetitive motivations. If organizations which employ health care personnel demonstrate that they will not substitute the Rube Goldberg for the Dr. DeBakey in open-heart surgery and consent to bear the full responsibility for ensuring that quality care will be rendered on penalty of organizational liability, why keep personnel licensure?

The exception preserving licensure for the physician is bred from a deep-seated fear (and concern that physician political opposition is so easily translatable into action against the advocates of objectionable change). There is no logical reason to keep it, except that the linkage between licensure and quality of performance may be more demonstrable with respect to physicians than with respect to other types of personnel. ${ }^{71}$ In addition, because the physician's license authorizes performance

\footnotetext{
${ }^{71}$ Physician acceptance of the proposal is not necessarily predictable. Although any change in the
} 
of all medical functions, the danger of unreasonable practice restrictions is not present as it is in the case of limited practitioners.

\section{B. Organizational Licensure ${ }^{72}$}

As noted earlier, licensure of organizations is not widespread. Evidence is available, however, that it is spreading. At this writing, Ohio has enacted into law a licensure scheme for health care organizations, ${ }^{73}$ and bills are pending in Georgia and Minnesota. The type of mechanism used to enfranchise health care organizations-licensing, chartering, certifying-is not in itself important. Whatever the mechanism, certain requirements can be imposed upon such organizations regarding their employment and utilization of personnel which will serve as surrogates for personnel licensure.

Naturally, if organizations rather than practitioners are to be licensed, such organizations must be accountable to the public. An organization authorized to do business by the state could be required to show, inter alia, (I) that its employed personnel (and consulting personnel, if any) (a) possess requisite training, $(b)$ possess training in specified fields, $(c)$ have $X$ amount of experience, and $(d)$ possess certification(s) from medical specialty boards, and (2) that capital equipment available for use by the personnel meets certain minimal conditions. ${ }^{74}$ Beyond this,

health care delivery system is generally opposed by organized medicine, there are signs that the AMA knee-jerk phenomenon is abating. For example, the Administration's Health Maintenance Organization development has been tolerated and upon occasion faintly praised, despite medicine's well documented resistance to prepayment and group practice arrangements.

${ }^{72}$ A distinction should be drawn. Licensure of organizations refers strictly to the control of organizations providing for or arranging for provision of health care services. The laws of most states govern the "financing" of health care services by indemnification of costs by commercial health insurance companies and by "service" plans like Blue Cross and Blue Shield. The law referred to here affects organizations providing health care services. The impetus for much of this activity is the Administration's recently announced health program which proposes stimuli to the development for health maintenance organizations. See note 43 supra. All configurations for such organizations are currently barred in 22 states and their development impeded in nearly all others. See, e.g., Aspen Sxstems Corporation, Group Practice and the Law (ig69); H. Hansen, Legal Rights of Group Health Plans: A Survey of State Laws Through I963 (1964).

Growing pressure to remove laws inconsistent with the evolution of health maintenance organizations will lead to the enactment of licensing and chartering mechanisms in many states to ( $x$ ) repeal other inconsistent state law, and (2) fashion regulatory schemes for such organizations.

${ }^{73}$ Ohio Rev. Code ANN. $\$ 1738.01$ et seq. (1964).

76 The Ohio law requires, for example, that certain conditions be met by an organization before it may do business. These include:

"§ 1738.04 Application for certificate or license.

Before it may issue any contract or certificate to a subscriber, a corporation not for profit desiring to establish, maintain, and operate a health care plan must obtain from the superintendent of insurance a certificate of authority or license to do so. Each application to the superintendent for such a certificate or license shall be verified by an officer of the corporation, and shall set forth, or shall be accompanied by the following:

(A) A copy of the corporation's articles of incorporation, and of any amendments thereto, certified by the secretary of state, which shall define with reasonable certainty the territorial boundaries within which such corporation proposes to operate a nonprofit health care plan, and which shall state the location of the principal office for the transaction of its business;

(B) A list of names and residence addresses of all officers and the trustees of the corporation;

(C) A description of the health care plan which the corporation proposes to operate, to- 
of course, the organization could be required to register all employed personnel with a state board and give notice to such board when any employee is terminated or resigns. The reasons for the termination could be certified as well. In this way intrastate and possibly interstate mobility of incompetent personnel could be impeded. The current licensure system possesses no mechanism which either systematically collects data on personnel performance, as reflected in malpractice litigation, or bases disciplinary action on poor performance unless performance data inadvertently comes to the attention of licensing boards. ${ }^{75}$

gether with the forms of all contracts or certificates which it proposes to insure under such plan;

(D) A statement of the assets and liabilites of the corporation.

" 1738.05 Issuance of certificate or license.

The superintendent of insurance shall issue a certificate of authority or license to any health care corporation filing an application in conformity with section 1738.04 of the Revised Code... and upon being satisfied that:

(A) Such corporation proposes to establish and operate a bona fide nonprofit health carc plan;

(B) The proposed contracts and the proposed rates therefor between such corporation and the subscribers to the plan are fair and reasonable;

(C) The proposed plan is established upon a sound financial and actuarial basis, in vicw of the experience of nonprofit health care plans already in existence. If such corporation desires to amend any contract with its subscribers or desires to change any rate charged therefor, a copy of the form of such amendment of any contract or the change of any rate shall be filed with the superintendent of insurance and shall not be effective until the expiration of ninety days after the filing thereof unless he sooner gives to such corporation his written approval thereto. If the superintendent is not satisfied within such ninety day period, that any such change or amendment of either the contract or the rate is lawful, fair, and reasonable, he shall so notify such corporation and it shall thereafter be unlawful for such corporation to make effective any such change or amendment.

"§ I738.08 Annual report.

Every corporation subject to sections 1738.01 to 1738.21 , inclusive, of the Revised Code, shall annually, on or before the first day of March, file a report, verified by an officer of the corporation, with the superintendent of insurance, showing its condition on the last day of the preceding calendar year, on forms prescribed by the superintendent, which report shall include:

(A) The financial statement of such corporation, including its balance sheet and its receipts and disbursements for the preceding year;

(B) A list of the names and residence addresses of all its officers and trustees; and the total amount of expense reimbursement to all officers and trustees;

(C) The number of subscribers' contracts or certificates issued by such corporation and outstanding;

(D) The number of physicians and dentists with which such corporation has agreements and the qualifications of the physicians and dentists;

(E) The number and type of services covered under the contract or certificate provided during the year."

Id. $\$ \$ 1738.04-.05,1738.08$.

${ }^{75}$ In 1968, only 66 disciplinary actions involving either suspension or revocation of license were initiated against the more than 300,000 physicians practicing in the United States. Hearings of the Subcomm. of the Senate Comm. on Governmental Operations, 9oth Cong., Ist Sess. (I969). The question of professional policing of the quality of health care is germane, but too complex and of such magnitude as to be beyond the scope of this article. Suffice it to say that it has not worked very well. The scheme proposed offers much greater promise of intervention into the provider system to correct behavior not conducive to quality health care: First, because organizations would be responsbile for the quality of care and as such more amenable to "impersonal" and objective penalties should error occur than individual physicians whose penalization must be dished out by their pecrs; and second, because a new system offers the opportunity to introduce systematic "feedback" of poor 
It must be stressed that any organizational licensure scheme must be more than a mere enfranchising ritual-it must be a regulatory device. In addition to the provisions respecting health personnel, controls over organizational behavior inimical to the public interest must be secured. Since for-profit organizations will enter the field, careful consideration must be given to curbing profiteering and other practices incompatible with the delivery of a vital human service. ${ }^{76}$

\section{A Health Manpower Board}

This board would possess responsibility for the composition and performance of the health care labor force within a state. In the context of an organizational licensure scheme such a board would have four fundamental mandates: (I) to establish a registry scheme for manpower employed by health care organizations within the state; the registry would collect the data referred to above and possibly publish it as an aid to consumer choice between organizations; (2) to administer a certification system for nonphysician practitioners not employed by organizations and a licensure system for physicians generally; (3) to promulgate regulations regarding delegations by physicians and governing the certification process and related matters; and (4) to conduct a research and development program to improve the operation of the system and to develop new ways to measure the quality of health care services.

\section{A Medical Injury Liability System}

A discussion of the means to retread or dismantle the existing medical malpractice system is unnecessarily complicated for this article, even assuming such means exist. The troubles of malpractice are being addressed. A Department of Health, Education, and Welfare secretarial commission to consider this problem has recently been announced; surely a solution is in sight.

Under current law there is nothing to preclude an injured patient from suing an organization and recovering, as is demonstrated by the Darling case and its progeny. The individual practitioner remains, nevertheless, the prime target. Large health care organizations like the Mayo Clinic and the Kaiser-Permanente prepaid plans, however, have instituted indemnification arrangements to shield the practitioner from all but the first arrow from the plaintiff and in most cases to spare him the entire cost of defense and recompense. This expedient is certainly workable, although some practitioners may conclude, indemnification notwithstanding, that their exposure to litigation is increased in a group practice setting by the diffusion of management responsibilities for patients. But the cumbersome, random, rancorous nature of the litigation process for medical injuries suggests the need for development of a compensation system for such injuries based not upon fault but upon outcomes technology. While such a system is not at all a condition precedent to

performance to a corrective-disciplinary system. For a comprehensive examination of provider selfpolicing, see R. McCleery et al., One Life-One Physician (1970).

70 The Medicare amendments dealing with the health maintenance organization option do not prohibit payments to for-profit health maintenance organizations. See H.R. I, supra note 27. 
organizational development or the scheme proposed for control of health manpower employment and utilization, it is very consistent with the notion of organizational liability for health care services. ${ }^{77}$

There are seven major implications of the implementation of this proposal. Not all will eventuate, but most are highly probable. First, efficient utilization practices by large health care organizations (the best able to institute them) would be sanctioned. Second, entry barriers to the employment of many poor and near poor persons who do not possess gilt-edged credentials but who have or can be trained to have health care skills, will be eliminated. Third, the strangleholds over health care organizations and practice held by organized health care professions will be lessened, leading to increased and continued organizational development and more economical and efficient practice, including increased use of medical hardware. Fourth, an incentive to growth of large health care organizations will be created. Fifth, health care cost escalation should be slowed by economies instituted by health care organizations relieved of unreasonable manpower employment and utilization constraints. Sixth, providers, principally physicians, will be encouraged to make patient care decisions free from some of the restraints posed by the threat of malpractice litigation. And finally, for better or for worse, the seemingly endless and herculean task of dragging the health care system into the twentieth century will be advanced.

\footnotetext{
${ }^{77}$ See note $3^{8}$ suspra.
} 